Historic, Archive Document

Do not assume content reflects current scientific knowledge, policies, or practices. 



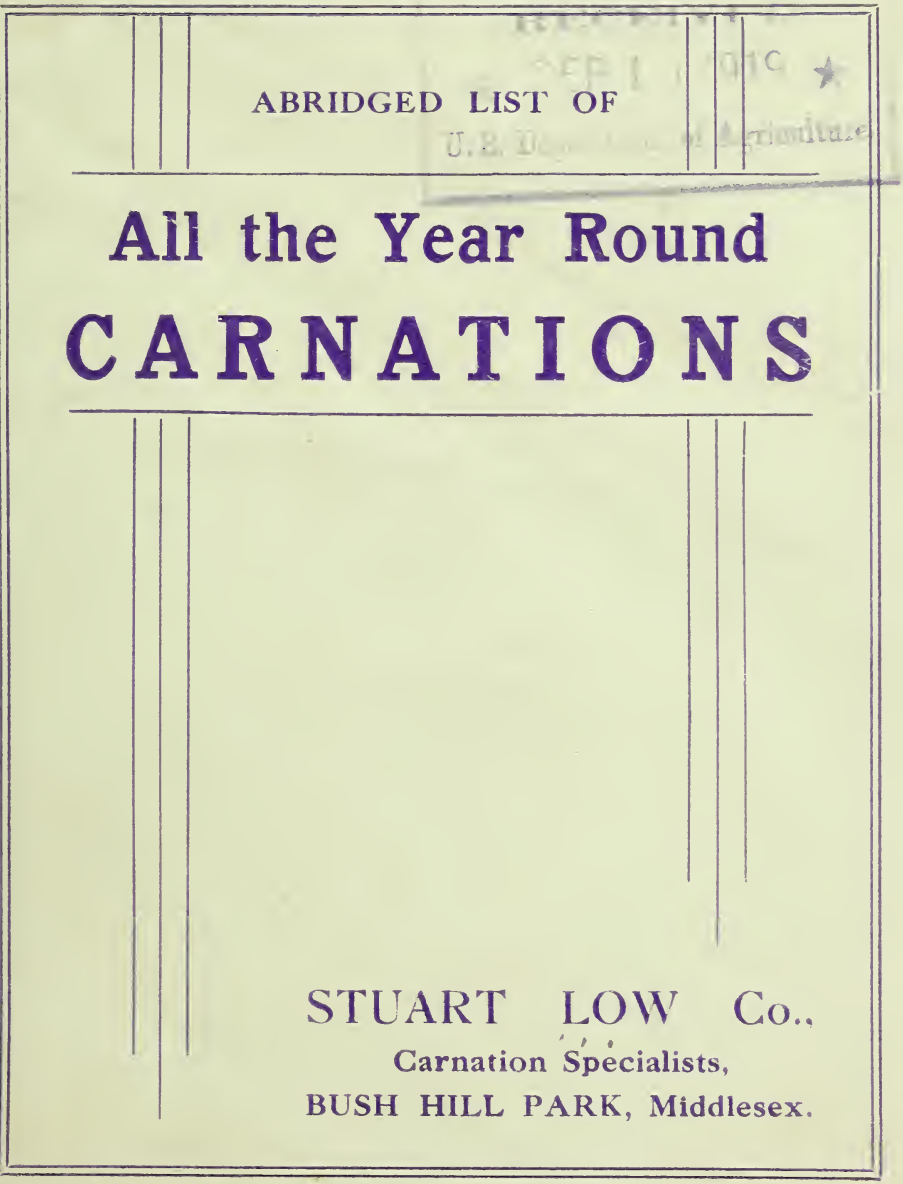




\section{PRICES OF PERE}

Section In 3in. pots.
A are each
9d.
,. , per doz.
B ,, each
,C ," per doz.
C ,, each
., ,, per doz.

In 5 in. pots.

$1 / 6$

$17 / 6$

$1 / 6$

$17 / 6$

. $2 /-$

20/-
In 6 in. pots.

$$
\begin{gathered}
2 / 6 \\
24 /- \\
2 / 6 \\
24 /- \\
2 / 6 \\
24 /-
\end{gathered}
$$

Prices per dozen apply to qua itie

We advise our clients to leave us latitude in selection

\section{Pink Varieties.}

\section{Alice B}

Alice Coombs F

Baroness de Brienen A

Bedford Belle E

Colleen E

Elsenham Beauty A

Empire Day A

Enchantress Supreme A

Good Cheer D

Gorgeous A

Lady Alington A

Lady Fuller A

Lady Meyer A

Lady Northcliffe A

Laura Weber B

Lucy A

May Day A

Mary Allwood A

Mrs. C. W. Ward A

Mrs Mackay Edgar C
Nora West F

Philadelphia A

Pink Sensation C

Queen Alexandra A

R. F. Felton A

Rose Pink Enchantress A

Salmon Britannia A

Salmon Enchantress $A$

Salmon King A

Satin Robe A

Winsor A

\section{White Varieties.}

Matchless A

Snowstorm A

Mrs Lloyd Wigg C

White Britannia A

White Enchantress A

White. Perfection A

White Wonder A

Wivelsfield White C

\section{STUART LOW Co.,}




\section{UAL CARNATIONS.}

Section

$D$ are each

In 3 in. pots.

$1 / 6$

", , per doz. 15/.

E , each

,., per doz. 18/-

$F$,, each 26

, ,, per doz. 24/-
In 5 in. pots.

26

24! -

36

36 -

36

$36 /$ -
In 6in. pots.

36

36 -

5 -

54 -

5 -

$54 /-$

not less than 6 of any one sort.

s to secure having the finest stock available at the moment.

Crimson Varieties.

British Triumph A

Carola A

Pocahontas A

Princess Dagmar A

\section{Reds and Scarlets.}

Aviator D

Beacon A

Belle IVashburn E

Britannia A

Champion A

Countess of Pembroke D

General Joffre E

Mrs. Clode A

Nebraska E

Scarlet Carola D

Scarlet Glow A

St. Nicholas A
Mauve and Fancy Varieties.

Benora A

Bishton Wonder D

Circe C

Elsie Boyd B

Fairmount A

Geoffrey Henslow D

Mauveen B

Mikado A

Mrs Crook A

Purple Robe B

\section{Yellow Varieties.}

Premier $A$

Saffron $36 \& 5 /-$ each

flowering size

Sunstar A

Yellow Prince B.

Yellowstone B 
Perpetual Malmaisons A new class of giant flowers. Treattions, i.c., a temperature of 48 to 54

Ceres, blush
Hon. Charlotte Knollys, the largest carna-

tion in commerce. An immense red

Lady Miller, blush ...

Marmion

Mrs Myles Kennedy, a perpetual flowering

form of Princess of Wales

Mephisto, orange flame ...

Minerva, cerise

Mrs Raphael, bright red

Mrs Gott, white

Princess Juliana

Venus, white, veined pale pink

Young

Plants.

$2 \longdiv { 6 }$

$7 / 6$

$1 / 6$

$1 / 3$

$7 / 6$

$3 / 6$

26

$1 / 3$

$1 / 6$

$1 / 3$

$2 / 6$
Flowering

Plants.

$3 / 6$

The Set of the above eleven varieties in young plants for 24/. 10 plants of flowering size for $40 /$ -

We still have a fine collection of the old type including Old Souvenir de la Malmaison. List of sorts on application.

\section{Perpetual Carnations for Out Door Planting.}

No other carnation excels these for border planting if specially prepared plants are obtained. Price, large plants 12/- doz.

Our book "Perpetual Carnations" a complete manual on the cultivation of carnations. $1 / 4$ post free.

\section{STUART}
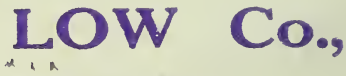

CARNATION SPECIALISTS,

BUSH HILL PARK, Middlesex. 